\title{
The Readiness Level of Using e-Learning Among Teacher Graduate Programme (TGP)
}

\author{
${ }^{1}$ Noorazman Abd Samad, Wan Mohd Rashid Wan Ahmad, Hairuddin Harun, Siti Noor Fazelah Mohd. Noor, \\ Affero Ismail, Mohd Wafi Abd. Rahman, Randy Justin.
}

${ }^{1}$ Faculty of Technical and Vocational Education, Universiti Tun Hussein Onn Malaysia,

\begin{abstract}
Using e-Learning among Teacher Graduate Programme (TGP) to students who are newly exposed in Teaching and Learning (T\&L) proses. The major problem among student's TGP is the readiness level in knowledge, attitude and skills using e-Learning during Teaching and Learning (T\&L). This study is to identify any significant differences of the knowledge level between male and female TGP students. The design of this study is to survey research using instruments of questionnaire which are distributed to respondents among TGP students at the Faculty of Technical and Vocational, UTHM. The sample is given to 248 respondents and analysis using version SPSS 21.0. Data presented using descriptive method such as, Mean, Standard Deviation(SD), inferens statistic using Mann-Whitney $U$ to identify the knowledge difference between male and female TGP students. The result showed that the level of application of e-Learning among TGP students in terms of knowledge, attitude and skill at moderate level. The study also showed that there are no significant knowledge difference among male and female TGP students because the result of $p=0.044$ value is less $<0.05$ can be stated that $\mathrm{Ha}$ failed rejected. The results of this study is important to provide awareness especially to the TGP students, lecturers and also UTHM in providing new T\&L using eLearning.
\end{abstract}

Keywords: e-Learning, attitudes, skills, knowledge

\section{Introduction}

Globalization leads to cultural change, social and political. Nowadays, the concept of a borderless world makes learning globally, liberalization and global change information exists is because of the globalization. According [6] advocated that Information and Communications Technology (ICT) have a huge impact on the shift change and the management of education systems in developing countries such as Malaysia. ICT is also a need in everyday life due to the use in the increasingly sophisticated today. Life on this day is much dominated by ICT, while the future development of a country is dominated by the development of science and technology.

The development of science and technology is closely linked to the education system in Malaysia. [20], stated that the learning system is one of the factors that affect the competence of approval among students. Changes in the education system had $n$ developed quite rapidly in line with the development of ICT that has brought a huge change for the advancement of education. The development of the learning method also had undergone many changes, both for individual learning, instructional media, and the learning process. According to [5] and [17 ], the change is based on the development of ICT. However, students need to have satisfaction with tradisional learning system before e-Learning can be implemented.

The disadvantage of tradisional learning needs to be improved in terms of delivery of instruction for teachers to overcome. The statement is in line with [13] where it is believed that tradisional learning system is ineffective due to the rapid technological developments and will cause institutions that still use traditional learning systems be left behind. Technological transition will leave tradisional learning and in turn to e-Learning.

Therefore the development of education in Malaysia started with the traditional teaching which adopted the teacher-centered approach and widely used in 21st century education. [15] stated that some teachers use methods of

*Corresponding author:noorazman@uthm.edu.my 
speaking and writing (chalk and talk) and oneway communication only. This method had proved that fast learners get bored easily and had caused students to be more passive. The learning process should be dependent on the teaching content in the classroom. According to [2], the development of internet usage leads to on-line learning, better known as e-Learning. ELearning is one of the alternative methods used today for traditional learning methods against the weakness in terms of one-way communication between students and teachers. According [16[, also argues that, communication between teachers and students, students and students and students with the global web of material occurs in the shortest time through this network and electronic learning makes students not only active but also responsible for learning.

This statement was also supported by [2], where students can make plans and find information with its own efforts and initiatives. Information search is not limited because the materials can be selected by the student, whether perceived or not. Students do not shy to repeat the same title to achieve the level of satisfaction of their understanding before moving on to other topics. In addition, its more flexible and less time pressure because it can be done anywhere as long as there is a computer and internet facilities.

\section{Research Problem}

The use of e-Learning in Malaysia is still new compared to the developed countries, where e-Learning is used as teaching and learning process But according to the study [14], the lack of e-.Learning is limited only to download and upload by lecturers and students involved in a class or lecture only. Therefore, there is constraint information transmitted from several parties such as lecturers and students using e-learning. This statement is in line with reality [17], who stated that students who possess positive attitude towards computers are also more willing to use it compared to the students who have a negative attitude toward computers

The obstacle that led to the implementation of e-Learning is the difficulty to achieve information and a lack of students' skills in using e-Learning. Based on studies by [1], found that meaningful e-Learning can be achieved through the use of the resources available from the internet by students. However, this situation will not happen if the teacher lack the knowledge that can help facilitate the use of ICT among students.
According [8], stated that in the process of implementing a program of computer-based information technology proficiency among teachers is required. It is important not only to improve the effectiveness of teaching and learning but also from the administration and management of schools.

Among other obstacles identified are lack of knowledge. Knowledge refers to certain levels of knowledge belonging to the individual [22]. Therefore, it is closely linked to experience and expertise. According to [6], knowledge and attitudes towards computers is affected by the frequency of computer use, the more often a person uses a computer, knowledge level will also rise. The level of knowledge of information technology teachers can be improved through information technology courses. The study [8], shows the role of teachers who are less skilled in producing electronic teaching materials of high quality and difficult to form a teaching based on the level of knowledge and skills in a variety of e-Learning delivery failed to achieve effectiveness.

Based on the issues described as traditional learning weaknesses and failures of the use of e-Learning, the study of the use of e-Learning in learning among the students of TGP can be very effective since they are the main focus. Therefore, e-Learning is an innovative method to improve the effectiveness of teaching and learning process. But awareness and readiness for change among students and lecturers is also an important factor in determining the success of e-Learning.

\section{Research Questions}

The study was conducted to find answers based on the objective in this study. The research questions is :

i) What is the level of readiness of TGP students in the application of e-learning from aspects of knowledge to the teaching and learning process in UTHM?

ii) What is the level of readiness of TGP students in the application of e-learning from aspects of attitudes to teaching and learning processes in UTHM?

iii) What is the level of readiness of TGP students in the application of e-learning in terms of skills for the teaching and learning process at UTHM?

iv) Is there a significant difference in the level of readiness of TGP students in the aspect of 
knowledge in the application of e-learning between male and female students?

\section{Methodology}

The design of this study is using survey design. According [10], the survey methods should be used to obtain samples of a large size because the process using other methods is difficult and complex study design is used as a guide to find a clear answer to the question.

\subsection{Population and Sample}

Sample is a subset of the study population or part of the population. The study involved population 725, TGP students Cohort 1 at UTHM. The number of samples to be used are a total of 248. This representing a large population, sampling was used to take part set of respondents from this population [3]. Rational use of samples is to facilitate the review to be carried out. Use the sample is large enough to represent the entire population regardless of population studies using proper sampling method [10].

\subsection{Research Instrument}

Questionnaire as a instrument tool consist Part A- Demographic, Part B- Knowledge, Part C- Attitude and Part C- Skill that have been developed with items Likert scale. Data is analyzing using SPSS Version 21.0. Data presented using a descriptive analysis such as Mean, Standard Deviation (SD) and inferens statistic such as Mann-Whitney U.

\section{Result}

Demographic analysis shows the number of female participants noted that the number of respondents was higher, namely 130 respondents $(54 \%)$ than male respondents were 114 respondents $(46 \%)$. The difference in number of female respondents and male respondents in total of 20 respondents $(8 \%)$. The total number of male and female respondents is 248 people $(100 \%)$. Analysis of demographic (gender) is required to analyze if there are significant differences in the level of readiness of TGP students in the application of e-Learning between male and female using Man-Whitney.

From the data analysis, the data showed that the overall level of readiness students' knowledge, skill and attitude among TGP to use e-Learning is still moderate level. The overall result average is the mean value of knowledge mean $=3.26$, attitude mean $=2.94$ and skills mean= 2.97. Mann-Whitney $U$ test shows the result of the score no difference between male and female TGP students knowledge in the application of e-Learning. This is from the results obtained the value of $\mathrm{P}<0.05$. This means the value 0.044 and value is less $p<0.05$ can be stated that $\mathrm{Ha}$ failed rejected.

\section{Finding And Discussion}

Students' TGP knowledge, skills and attitude is importance refers to the level of their readiness in e-Learning because its provides control over the computer, knowledge and perception of eLearning. This results showed that the level of students' knowledge, skills and attitude among TGP student's using e-Learning is still at moderate level. This findings also revealed that , most respondents have knowledge of eLearning at a moderate level. This assertion is supported by a study of the [19], who stated at the beginning of the use of information technology requires knowledge in the handling of equipment and software. He also said if someone trainers are not knowledgeable in technology it is difficult for them to fully express the meaning clearly. The statement was in line with reality [11] that an educator should enhance knowledge in the field of technology to build a deeper knowledge in the field. Apart from attending the course, teachers also need to explore all science-related technologies that are widespread on the Internet [12]. TGP students' attitudes rather get learning materials directly than do discussions and also active as leaving comments on social services author system. In conclusion, the student TGP attitude towards the application of e-Learning is still at a moderate level. Student TGP should be a change of attitude towards e-Learning and also there should be awareness of the use of computers to improve their ability to use technology. Skills level of TGP student's used e-Learning is still a moderate level. From the research conducted, most of the respondents have moderate level of skills using e-Learning, this also shows their readiness is also at a moderate level.

Consequently skills are very important in the application of e-Learning in which skills students need to be in line with TGP knowledge so that it can be applied perfectly. For example in the use of power point slides, without knowledge, creativity and skills, chances main objective of attracting students to focus on the course will not be obtained [9]. This is because the interface is creative and draw attention to prevent students from getting bored and can 
help students to better understand the information to be communicated clearly. The statement in line with the statement by the [18], where the skills and knowledge must be reconciled. Lack of knowledge will cause it to be a constraint in the use of information technology as well as the teaching and learning process. Therefore, the skills and the use of technology will not be obtained without knowledge.

Mann-Whitney $U$ test was conducted to see whether there are significant differences between the level of readiness of students TGP in knowledge application of e-Learning between male and female. The findings show that there are differences between the level of readiness of students TGP in knowledge in the application of e-Learning between male and female. Therefore, it is concluded that there are significant differences between male and female students against the use of e-Learning knowledge TGP students at the UTHM.

\section{Conclusion}

Overall findings of this study can have implications for UTHM especially lecturers on the importance of e-Learning in teaching and learning process. In addition, this study is also expected to bring awareness to students in UTHM in order to make use of e-Learning to improve the quality of teaching and learning more effective. In addition, the administration can also take advantage of in-campus study as an opening to find the best way to produce lecturers who are able to perform their teaching and learning effectively. Based on the findings showed that the application of e-Learning is still at a moderate level.

Therefore, this study is very important to our students to build on the existing system especially using author system. UTHM needs to constantly improve the quality of e-Learning systems and appropriate to the needs of lecturers and students so that they can enjoy optimal use of e-Learning. With the studies like this then it will make it easier for our students to know the weaknesses in systems in particular, author. Therefore, UTHM can design the best strategy to implement the use of e-Learning graduates in their learning process. The issue of this research, the researchers want to overcome the system of e-Learning undertaken by students TGP to improve the quality Teaching \& Learning (T\&L) but the results showed e- Learning is still at an average level. The main factor researchers realize that online learning or e-Learning is still new for to students to use of e-Learning among students TGP should be upgraded among TGL students in T\&L at UTHM

Acknowledgement to U226 - RSGS (Research Supporting Grant Scheme), ORICC Universiti Tun Hussein Onn Malaysia (UTHM).

\section{References}

1. Abu Bakar, R.. Kajian Terhadap Penggunaan Perisian Dan Perkakasan Multimedia Di Kalangan Guru Dalam $P$ \& $P$ Di Sekolah Menengah Zon Skudai., Tesis. Universiti Teknologi Malaysia,(2009)

2. Abdul Rahman M.A. \& Shamsudin, F. Penggunaan E-Pembelajaran Di Kalangan Pelajar Jabatan Pendidikan Teknik Dan Kejuruteraan, Universiti Teknologi Malaysia. Penggunaan E-Pembelajaran Di Kalangan Pelajar Jabatan Pendidikan Teknik dan Kejuruteraan,. Tesis (Unpublished). Universiti Teknologi Malaysia (2010).

3. Chua, Y.P. Kaedah dan Statistik Penyelidikan:

Kaedah Penyelidikan. Kuala Lumpur: McGraw Hill (Malaysia) Sdn. Bhd. (2006).

4. Daud, S. M., Hashim, Y., \& Saleh, M. N. FaktorFaktor Yang Mempengaruhi Keberkesanan Pengajaran Dan Pembelajaran Melalui Sidang Video Dalam Pendidikan Jarak Jauh. Malaysian Journal of Distance Education, 2(1), 67-90 )$(2000)$.

5. Graham,C.R.,Allen, S.. Designing Blended learning Environments, 562-570.In encyclopedia Of Distance Learning Vol.2. (2009).

6. Hassan, J., \& Kamisan, S. N.. Halangan terhadap penggunaan komputer dan ICT di dalam pengajaran dan pembelajaran (P\&P) di kalangan guru di sekolah menengah kebangsaan luar bandar di daerah Kulai Jaya, Johor. N/A, 1-10. (2010).

7. Hassan, J., Rahman, A., \& Rashida, F. Penggunaan ICT dalam proses pengajaran dan pembelajaran di kalangan pendidik Fakulti Pendidikan Universiti Teknologi Malaysia, Skudai, Johor. Unspecified, 1-9. (2011)

8. Ibrahim, N., Wong, S. L., \& Ayub, A. F. M. Sikap terhadap Komputer di kalangan Pelajar ICT Tingkatan Empat. Jurnal Teknologi Pendidikan Malaysia, 1(1).(2011).

9. Kassim, Z. \& Ahmad, A.R.. E-Pembelajaran: Evolusi Internet Dalam Pembelajaran Sepanjang Hayat .Proceedings of Regional Conference on Knowledge Integration in ICT 2010.209-218. (2010).

10. Konting,M.N. Kaedah Penyelidikan Pendidikan. Kuala Lumpur. Dewan Bahasa dan Pustaka.(2004). 
11. Krishnan, J., Said, M., Haruzuan, M. N., Atan, N. A., \& Hassan, J. Faktor-Faktor Yang Mempengaruhi Penggunaan e-Pembelajaran Di Kalangan Pelajar Tahun Akhir Fakulti Pendidikan, Universiti Teknologi Malaysia.(2007).

12. Mohamed, W., Azlinda, W., \& Hassan, H. Hubungan faktor demografi dan faktor literasi komputer dalam menentukan kesediaan pekerja industri terhadap e-Latihan.(2010).

13. Mohd Balwi, M.K.Perkembangan Pembangunan dan Penerimaan e-Pembelajaran Di Institusi Pengajian Malaysia. Jurnal Teknologi, 41(E), 5572.(2014).

14. Omar,R, \& Ahmad,J. Kesedaran,Penilaian dan Penerimaan e-Pembelajaran dalam Kalangan Ahli Akademik. Jurnal Pendidikan Malaysia 34(1) (2009):155-172. (2009).

15. Ramli, M.E.J..Hubungan antara tahap kesediaan Pembelajaran Arahan Kendiri Dengan Tahap Penggunaan E-Pembelajaran Di Kalangan Pelajar Di Universiti Tun Hussein Onn Malaysia Batu Pahat, Johor. Tesis Sarjana, .Universiti Teknologi Mara.(2009).
16. Rahman, A., Anuar, M., \& Ibrahim, E. Y. Penggunaan E-Pembelajaran Dan Hubungannya Dengan Pencapaian Akademik Pelajar Di Fakulti Pendidikan, Universiti Teknologi Malaysia, Skudai, Johor., 1-7.(2010).

17. Singh,H..Building effective blended learning program, Educational Technology, 43(6),pp 5154.(2003).

18. Suhaini, M. Kompetensi Pelajar Dalam Aplikasi Komputer Bagi Pembelajaran di Kolej Vokasional Pahang, Tesis Sarjana, Universiti Tun Hussein Onn Malaysia (2014).

19. Su, L. T. Kemahiran teknologi maklumat di kalangan pelajar Fakulti Pendidikan, UTM dan hubungannya dengan sikap terhadap ePembelajaran. Universiti Teknologi Malaysia, Faculty of Education.(2007).

20. Tahar, I. Hubungan kemandirian belajar dan hasil belajar pada pendidikan jarak jauh. Jurnal Pendidikan Terbuka Dan Jarak Jauh, 7, 91101.(2006).

21. Yaacob, M., Zainab, A. N., Edzan, N. N., \& Abdullah, A. Teknologi Maklumat dan Komunikasi (TMK) pengupaya masyarakat Melayu berasaskan pengetahuan. (2002). 